\title{
FOREIGN EXPERIENCE IN THE FORMATION AND DEVELOPMENT OF FAMILY BUSINESS AND THE POSSIBILITIES OF THEIR IMPLEMENTATION
}

\section{Yuldashev Doniyor Tairovich,}

Teacher of "Economy" department of the Fergana State University of the

Republic of Uzbekistan

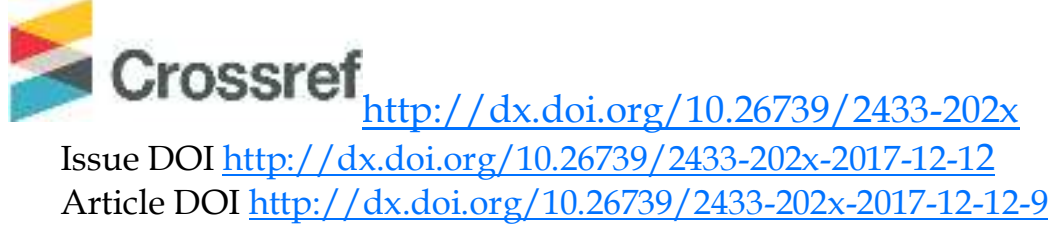

\section{Abstract}

The article describes foreign experience in the formation and development of family businesses in the example of Germany, Holland, Italy, Finland, USA, France and India, as well as its grouped existing types of family business management in different countries of the world, and provides scientific recommendations on the effective organization and management of the activities of the family business. The development of family business in Uzbekistan, the research of foreign experience in this field and consideration of their accessibility are priority.

Keywords: family business, stockholder, member of family business, company, corporation, enterprise.

Historically, the experience of the family business for many years has been an important type of business.Professor William H. Uhara, director of the Smithsonian College's Family Business Institute in Rhode Island, Roddale, USA, wrote in his book "Century of Successes": "Family business existed before the creation of transnational corporations. Family business arose before the industrial revolution. The family business existed before the Greek and Roman empires ... ". "The Family Business" magazine listed several hundred family businesses with over 200 years of service life[1].

Yuldashev Doniyor Tairovich 
At the same time, family business is a relatively common form of business.According to the data, family business in the world accounts for about $70 \%$ of all companies, up to $80 \%$ in the United States, and $94 \%$ in Finland [2]. The researchers found that 68 percent of Western small businesses are family businesses [3].

Nowadays, the role of family business in the economy of the world is increasing. The majority of studies have focused on the types of international decisions of family firms, it is also true that they have focused almost exclusively on the two classic decisions of internationalization: commitment and market selection [4]. In general, in many foreign countries, the role and value of family business is great. For example, today's world-renowned family business is an example of Rotshilds - Bankers' family (France), Opel Automotive (Germany), Sharl Tisso - Tissot watches, Oral-B, Siemens, Adidas, Samsung Electronics and others [5].

It is important to consider the role of family entrepreneurship in the economies of the developed economies.For example, family business is one of the most important components of American business. US \$ $24 \mathrm{~m} 62 \%$ of all workers are employed in family businesses, and their share in GDP is $64 \%$ [6].

In Germany, more than $90 \%$ of the business is concentrated in the hands of family businesses. The majority of them are family owned companies, which are managed by several generations.Such firms have permanent customers who have been formed over the years. Recent research shows that small firms are able to shape their markets through narrow specialization and to judge their own. Closure of leading family companies can lead to the stagnation of the entire market.

In Germany, there are about 3,4 million small and medium-sized enterprises, providing 20 million jobs. Family businesses are the backbone of the German economy. It accounts for $85 \%$ of all industrial enterprises in the country, and in turn will provide 3 million jobs[7].

Germany is characterized by not larger cities than many other countries in Europe.When the country provides inadequate jobs, this creates difficulties for the government, but small businesses can help in this and succeed.Family business plays a "significant role in the local economy." Moreover, according to statistical research, family business in Germany is based on the "human factor".Traditions in this country are highly esteemed, firms that have been in the market for more than a hundred years are treated with great respect than foreign famous brands[8]. 
In the Netherlands, small and medium-sized enterprises cover $98.5 \%$ of all private enterprises, of which $90 \%$ are small businesses. Small and medium enterprises employ more than half of those employed in the private sector. The Netherlands occupies a leading position among the EU countries in terms of employment in the service sector.

In the Netherlands, family businesses are mainly grown in the agricultural sector. For example, on the farm of William Dexter, an average of two and a half people work - husband, wife and employee. 120 cows on the farm give an average of 1 million liters of milk. William's brother Elohim Dexter has a cheese factory where William delivers the milk. In cheese factory also employs two people, that is, his brother and his assistant. They produce 100 tons of cheese per year.

More than $90 \%$ of companies in Italy are owned by one family. In Italy, the number of enterprises employed by up to 50 people accounts for about $90 \%$ of the total production.In Finland, $90 \%$ of the total business is familyowned microfirms with less than 10 employees.

India is called the country of family business. 95\% of all registered companies are family entrepreneurs[9]. According to some analysts, $80 \%$ of all small and medium enterprises in certain sectors of the Russian economy (eg agriculture, food industry, textile industry, IT-technologies and trade) are family businesses[10].

As the development of family business in Uzbekistan has been selected as one of the key areas, it is desirable to take into account the practical experience accumulated over the years in the world.Especially, it is important to determine the composition of the family business, that is, the strict approach to employment.A great deal of attention is paid to the issue of family business in developed countries. Despite the fact that business partners or those who want to work there are mostly members of their families, they are very careful and responsive on their choice. It is noteworthy that some foreign family firms require that family members work for 10-15 years in other companies before joining a family business[11].

Usually, there is a personal trust relationship, known as the fiduciary family business.For example, the transfer of property to trust management depends on the existence of personal trust between the parties" [12]. From a legal point of view, fiduciary operations are more reliable and progressive than contractual obligations. In such relations there is no need to sign, promise, collect information about a partner.The mutual influence of the parties is based on trust and close kinship relationships, and not on risk, for example, the obligation between the founder and the trustee executive Yuldashev Doniyor Tairovich 
manager [13]. In the development of the family business in Uzbekistan, mutual trust between family members should become an important source for solving many business problems.

To study the stability of family business is crucial. The research has shown that some scientists and experts have concluded that family businesses often ends their activities very quickly. This is not a straightforward comment, and William A. O'Hara, quoted above, on the question "What is the most robust and long-lasting business?" answers "family business"[14].

Nevertheless, in some cases, statistics show instability in family business activities.In particular, according to the experience of developed countries, despite the fact that the history of several family companies covers several hundred years, only 5\% of such companies remain to the third generation.The biggest danger for such companies is the second generation of owners. Because in many cases, heirs who have adopted are less likely to be enterprising and motivated than the founders of the business, but they try to convince them that they will manage their business. When it comes to the third generation, there is a conflict between the individual members of the family and the common seed of the clan. There are many examples, Cargill in the United States, Samsung in South Korea, BMW in Germany, Clarks Shoes in England, and LVMH companies in France [15].

From this we can conclude that in the family business, usually many companies and families are destroyed for the heritage. Therefore, the need to develop and legalize certain inheritance rules is of paramount importance in world practice.

For example, the beer brewing company Bavaria has its own rules of transferring management to a new generation. According to them, if the manager turns 62, he will have to retire and leave the company. After that, he can no longer participate in the company's activities. Because at the age of 40 to 50 years there is a risk that the company's management will be at the age of 70 years and older. It's a little late to hold a position in 40-50 years [16].

Similar rules apply to the world-famous Wal-Mart trading network, the Bertelsmann international publishing polygraph, the Canadian train and plane company Bombardier[17].

According to Grant Gordon, Co-founder and CEO of Institute for Family Business, author of Family Wars, one of the major difficulties in bringing the business to the next generation is the disagreement among the generations.This is a frequent problem facing family business owners. The essence of the conflict between generations is usually manifested by the Yuldashev Doniyor Tairovich 
impatience of young people who face the conservatism of older generation.Gordon thinks that in spite of all the negative consequences of the disagreements, they can lead to positive news, new thinking [18].

Michael Sullivan, head of the UK's Credit Suisse Private Banking, explains: "Our research confirms the importance of family business in supporting the UK economy.Despite the fact that this sector is largely ignored by the British government, the role of family companies in other countries' economies can be seen as a good opportunity for regional development and enterprise development.The global financial crisis has highlighted the importance of a long-term economic development strategy, which includes the priority development of regional economics and family business" [19].

Business performance may be affected by the family nature of a company, especially by its ownership structure and corporate strategies. In this sense, governance and resources of family firms are key determinants of outcomes such as the continuation of family involvement and firm survival [20].

It can be seen that in Uzbekistan, through the development of family entrepreneurship, it is possible to effectively address the issues of ensuring the socio-economic development of different regions of the country.

In many countries of the world, family businesses can be grouped into two groups, depending on the structure and location of capital, as well as on the management of the organization and the size of the enterprise(Picture 1).

The first group is a family business, that is, a family and close relatives. As a rule, this small enterprise employs up to 10 employees. At the same time, it is possible to single out individual subgroups in the form of a family (that is, only close relatives - husbands, wives, children).Such firms are family companies in Canada, the USA and Russian Federation [21]. Firstly, these are different types of individual entrepreneurship.

In such companies, duties on positions, subordinate and hierarchical stages are not defined. Leadership refers only to the head of the family, while others perform their work with their own understanding. Typically, the small shops, consulting companies andprinting houses are operating on this principle.No job descriptions. Operational replacement of functional positionsoperates.

Another subgroup is the business of families with several relatives. This is usually a family business that has a well-organized and governed structure, and family relationships have become a business relationship, 
some of the family members become managers, and some of them some of them become their employees.

The second group of family businesses are companies that are inherited from generation to generation, all of whom are family pedigrees.

This group includes large and larger companies, usually in the form of international corporations, which include many branches. In this case, the family controls the company only through a package of family shares. Each family must have a share in the family with a different percentage of shares in order to have the right to manage the family business.

\begin{tabular}{|c|c|c|}
\hline \multicolumn{2}{|c|}{ Family business } & \\
\hline \multicolumn{2}{|c|}{$\begin{array}{c}\text { The company of the family members and their } \\
\text { relatives }\end{array}$} & $\begin{array}{l}\text { The firms of the } \\
\text { family pedigrees }\end{array}$ \\
\hline \multirow[t]{2}{*}{ One family business } & \multirow{2}{*}{$\begin{array}{c}\text { The family business } \\
\text { with relatives }\end{array}$} & \\
\hline & & 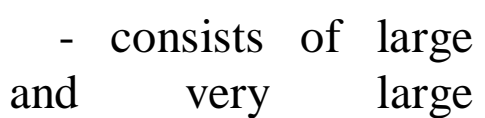 \\
\hline $\begin{array}{l}\text { - mainly consists of } \\
\text { different types of individual } \\
\text { entrepreneurship; } \\
\text { - responsibilities of family } \\
\text { members are not distributed; } \\
\text { - there is no subordination } \\
\text { structure, no hierarchical } \\
\text { stages; } \\
\text { - under the leadership of } \\
\text { the head of the family, } \\
\text { family members act } \\
\text { independently; } \\
\text { - there are no clear } \\
\text { provisions for this position; } \\
\text { - operational replacement } \\
\text { of functional positions } \\
\text { onerates }\end{array}$ & $\begin{array}{l}\text { - has clear } \\
\text { organizational } \\
\text { and management } \\
\text { structure; } \\
\text { - family } \\
\text { relationships } \\
\text { become business } \\
\text { relations; } \\
\text { - some of the } \\
\text { relatives turn into } \\
\text { managers and } \\
\text { some of them } \\
\text { become } \\
\text { employees. }\end{array}$ & $\begin{array}{l}\text { of 1nternational } \\
\text { corporations that } \\
\text { include many branches; } \\
\text { - the family controls } \\
\text { the company only } \\
\text { through a package of } \\
\text { family shares; } \\
\text { - the family must } \\
\text { have a different } \\
\text { percentage of shares to } \\
\text { acquire the right to a } \\
\text { family business; } \\
\text { - the remaining } \\
\text { shares must be } \\
\text { distributed among } \\
\text { many shareholders. }\end{array}$ \\
\hline
\end{tabular}

operates.

For example, in Finland, more than $50 \%$ of the shares, about $25 \%$ of shares in the United States and Germany are enough to have in the hands of Yuldashev Doniyor Tairovich 
the family. At the same time, these shares should be distributed among the majority of shares of this company, which is the largest shareholder of the company, and the remaining shares are on small shareholders.

In many countries, family firms are a leading form of business organization. Family businesses have a high level of crisis tolerance, due to the following factors: poor understanding of losses, not just immediate benefits, but understanding of the development prospects, understanding the capabilities of each participant in the company.

As it is knownthat, the family businesses constitute the basis of almost all the economies of the world. However, many researches show that family companies work better than non-family companies do.

In some countries, these businesses are $158 \%$ more productive than ordinary companies. These data were obtained during 10 years of research in the United States.

Today, there are two features for the global family business. First of all, it is important to save a large number of small and medium-sized enterprises, which are created by family members. For example, in the United States, such small family businesses have increased to 15 million. These types of family businesses are primarily aimed to save money on employee salaries. Because in Europe and in America, the value of hired labor is sometimes beyond the capability of newly established firms.

The second feature is the existence of large family corporations and holdings with a world-renowned and centuries-old history, which pass from generation to generation on the heritage of 3-6 times.

In England, where almost 16\% of all family firms are experiencing more than four generations of generations. Sweden has the largest share of familyowned businesses, with more than $60 \%$ of all employed population being occupied in this area. Italy 1.5 million people with a large percentage of family owned companies that have more than an euro turnover [22].

The world experience shows that family businesses are successful both in trade and in industrial industry, and in many cases reach the highest levels in the world and rank among the world's top companies.

Based on the above-stated opinion, it is possible to use the following foreign experiences in the development of family business.

1. Creating academic research areas and schools dedicated to family business.

2. Organization of conferences and seminars on this theme. 
3. Expand the list of training programs and have the opportunity to legally enforce the business succession and business succession through the activation of the Higher Education Institutions on the introduction of special subjects in family business management.

4. New mechanisms for financial support for innovation - use of innovative vouchers, checks, certificates. These tools are provided by the state for the purpose of paying for scientific research or consulting services by outside organizations (which ensures the proper use of state funds). 


\section{REFERENCES:}

1. Gizitdinova N. What is the family business in USA? http:// prodohod.blogspot.com/2010/04/blog-post.html

2. Transfer of business to children.www.voxpopuli.kz

3. Zhdanov A. Reefs of the family business. http://www.wmnspb.ru/rub/carier/391-rif.html

4. J.C.Casillas, A.M.Moreno-Menéndez, International business \& family business: Potential dialogue between disciplines, European Journal of Family Business, Volume 7, Issues 1-2, January-December 2017, pp.-25-40. https://www.sciencedirect.com/science/article/pii/S2444877X17300107

5. Family business or what is good and what is bad // http://www.bishelp.ru/svoe_delo/variant/7ya.php

6. Gizitdinova N.What is a family business in American? http:// prodohod.blogspot.com/2010/04/blog-post.html

7. The economy of Germany is based on the family business. finance.rol.ru

8. The economy of Germany is based on the family business. http:/ / finance.rol.ru

9. Gizitdinova N.What is a family business in American? http:// prodohod.blogspot.com/2010/04/blog-post.html

10. Toshmuhammedova D., Rizaev D. Family business: world experience. - http://www.bdm.uz/ru/birjaexpert/

11. What is a family business in Russian? //http://www.bishelp.ru/rich/Uspeh/otrasliRazv/0808semia.php

12. Concept and types of transactions // Civil law. http://www.grandars.ru/college/pravovedenie/vidy-sdelok.html

13. The legal basis of the family business in Russia // http://www.bishelp.ru/svoe_delo/

14. Gizitdinova N.What is a family business in American? http:// prodohod.blogspot.com/2010/04/blog-post.html

15. Transfer of business to children. www.voxpopuli.kz

16. The economy of Germany is based on the family business. http:/ / finance.rol.ru

17. Transfer of business to children. http://www.voxpopuli.kz

18. Transfer of business to children. http:// www.voxpopuli.kz

19. Family business and the UK economy - basic statistics

20. M.C.Pérez-Lopez, M.E.Gómez-Miranda, E.Argente-Linares, L.Lopez-Sánchez. The internationalization of Spanish family firms through Yuldashev Doniyor Tairovich 
business groups: Factors affecting the profitability, and the moderating effect of the family nature of the Spanish business, Revista de Contabilidad, Volume 21, Issue 1, January-June 2018, pp.- 82-90. https://www.sciencedirect.com/science/article/pii/S1138489117300225

21. Toshmuhammedova D., Rizaev D. Family business: world experience. - http://www.bdm.uz/ru/birjaexpert/

22. A Zahra, S. (2003). International expansion of U.S. manufacturing family businesses: the effect of ownership and involvement. Journal of Business Venturing, 18(4), pp.-495-512. 